\title{
Use of biostimulants in the development and productivity of soybean
}

\author{
${ }^{1}$ Lara Caroline Alves de Oliveira, ${ }^{2}$ Rubens Vieira Maia, ${ }^{1}$ Samiele Camargo de Oliveira Domingues, ${ }^{1}$ Marco \\ Antonio Camillo de Carvalho, ${ }^{1}$ Oscar Mitsuo Yamashita, ${ }^{3}$ Reginaldo de Oliveira, ${ }^{2}$ Priscila Porfírio Gonçalves
}

${ }^{1}$ Programa de Pós-Graduacão em Biodiversidade e Agroecossistemas Amazônicos, UNEMAT, Campus II - Avenida Perimetral Rogério Silva, 4930 - Jardim Flamboyant, Alta Floresta, MT. 78580-000, Brazil.

${ }^{2}$ Universidade do Estado de Mato Grosso, UNEMAT, campus II - Avenida Perimetral Rogério Silva, 4930 - Jardim Flamboyant, Alta Floresta, MT. 78580-000, Brazil.

${ }^{3}$ Programa de Pós-Graduação em Produção Vegetal, Universidade Estadual Paulista " Júlio de Mesquita Filho" UNESP. Faculdade de Ciências Agrárias e Veterinárias - FCAV, 7970 - Jaboticabal - SP. 14.884-900, Brazil

Correspondence Author: Lara Caroline Alves de Oliveira. Programa de Pós-Graduacão em Biodiversidade e Agroecossistemas Amazônicos, UNEMAT, Campus II - Avenida Perimetral Rogério Silva, 4930 - Jardim Flamboyant, Alta Floresta, MT. 78580-000, Brazil.

E-mail: lara.alvesoliveira@hotmail.com

Received date: 20 May 2019, Accepted date: 20 August 2019, Online date: 29 August 2019

Copyright: $\odot 2019$ Lara Caroline Alves de Oliveira et al, This is an open-access article distributed under the terms of the Creative Commons Attribution License, which permits unrestricted use, distribution, and reproduction in any medium, provided the original author and source are credited.

\begin{abstract}
Soybean cultivation has been cultivated throughout the country, with significant increases in productivity due to technological and scientific advances in the agricultural sector, and one of these advances is the use of biostimulants, which has shown positive effects on plant physiology and productivity. Thus, it is believed that, as a hypothesis, the treatment of soybean seeds with biostimulants based on hormones and micronutrients have a positive effect on the development capacity of plants and increase in the production of this crop. The objective of this study was to evaluate the effect of the use of biostimulants in the treatment of seeds, under the vegetative and productive components of the soybean cultivar Monsoy 8766 RR. The biostimulant used in the experiment was Stimulate ${ }$, composed of plant hormones kinetin, gibberellic acid and indolebutyric acid, and the mixed mineral fertilizer used was the GeoRaiz ${ }^{\circledR}$ Leg, composed of micronutrients of cobalt and molybdenum. The experimental design was completely randomized in the $5 \times 2$ factorial scheme, where the treatments consisted of a combination of five doses of Stimulate ${ }^{\circledR}$ stimulant $(0,0.35,0.75,1.10$ and $1.50 \mathrm{~L}$ ha-1) in the presence and absence of mixed mineral fertilizer Georaiz $₫$ Leg at the dosage of $1.50 \mathrm{~mL}$ per liter, with 4 replicates, totaling 40 sample units. The biostimulant had a significant effect on the number of pods, because when the dose increased, there was a decrease in the pods in $37.31 \%$. For the use of the Georaiz ${ }^{\circledR}$ Leg, there was no difference between its levels for the evaluated variables. Thus, it was concluded that the application of biostimulants in the treatment of seeds did not significantly influence the productive characteristics of the tested soybean cultivar.
\end{abstract}

Keywords: Production Components, Plant Regulators, Glycine max L

\section{INTRODUCTION}

Soybeans are the main oilseed crop in the world, with an expressive participation in human food. It is the fastest growing agricultural crop in production in recent years. And its cultivation is constantly boosted by the adoption of technologies such as pest management, disease and the use of high efficiency fertilizers (Hirakuri and Lazzarotto, 2014).

Faced with this, the search for increased productivity has always provoked the development of new technologies, such as the use of biostimulants (or bioregulators). These substances are classified as plant hormones: auxins, gibberellins and cytokinins are the most used (Dourado Neto et al., 2014). These bioregulators are natural or synthetic substances that bring benefits to plants are applied by spraying foliar or in the treatment of seeds and can inhibit or regulate the growth of plants. Its action can occur in the same place of synthesis or be translocated, acting in others parts of plants (Almeida and Rodrigues, 2016).

Recent studies point to a great potential in the use of biostimulants, which are important for increasing plant biomass, crop yield and resistance to multiple types of stress (Calvo et al., 2014; Nardi et al., 2016; Souza Neta et al., 2016).

By using these substances in crops, it is possible to contribute to nutrition and help minimize water stress, contributing to maximum yield ceiling (Castro and Vieira, 2006). Santos and Vieira (2005), using doses of cytokinin, indole butyric acid and 
Citation: Lara Caroline Alves de Oliveira, et al., Use of biostimulants in the development and productivity of soybean. Australian Journal of Basic and Applied Sciences, 13(7): 54-59. DOI: 10.22587/ajbas.2019.13.8.8

gibberellic acid, applied in cotton seeds, verified much more vigorous plants, in addition to the greater production of dry mass, in response to the applied doses of the product.

Other products may be associated with biostimulants, such as mixed mineral fertilizer-based commercial products, which provide cobalt (Co) and molybdenum (Mo). These elements are reported as substances that frequently cause deficiency in plants grown in Cerrado soils (Sfredo and Oliveira, 2010). Cobalt is considered a beneficial element for plants, being absorbed by the roots, because it is an important nutrient in the synthesis of cobamide and leghemoglobin in the root nodules, besides helping in the biological fixation of nitrogen (BNF). Molybdenum is considered an essential element for plants, and its main function is to participate in the respiratory activity of plants. In addition, it is a component of the enzyme nitrogenase, which is directly related to BNF (Lopes et al., 2014).

Biostimulants modify the structure and interaction with plant defense mechanisms, and when associated with micronutrients, play important roles in enzymatic activation and plant growth (Almeida et al., 2009; Prado et al., 2007). However, its efficiency depends on the site of synthesis or the plant tissue that is applied, the time of action, as well as the place of application. Therefore, the use of biostimulants and fertilizers in the treatment of seeds or foliar application is a method that requires research to prove its importance and its effect on plant cultivation (Weber, 2011).

The objective of the present study was to evaluate the effect of the use of biostimulants (hormones and micronutrients) applied through the treatment of seeds, under the vegetative and productive components of the cultivar Monsoy 8766 RR.

\section{MATERIAL AND METHODS}

The study was carried out between March and June 2016, in plastic pots within protected environment, belonging to the State University of Mato Grosso, Campus of Alta Floresta, Brazil. This locality is situated in the geographical coordinates $9^{\circ} 51$ '41,83' 'S, $56^{\circ} 04^{\prime}$ '09,61 " W and altitude of 283 meters.

For filling of the pots, soil classified as Red Yellow Latosol (Santos et al., 2013) was used. This soil was collected in the 0 $0.20 \mathrm{~m}$ depth layer and the chemical and granulometric characteristics are as follows: clay: $379 \mathrm{~g} \mathrm{~kg}^{-1} ; \mathrm{sand}^{-521} \mathrm{~g} \mathrm{~kg}^{-1}$ and silt: $100 \mathrm{~g} \mathrm{~kg}^{-1}$; $\mathrm{pH}$ in water: 5.5; $\mathrm{P}$ (mehlich): $4.8 \mathrm{mg} \mathrm{dm}^{-3} ; \mathrm{K}: 0.14 \mathrm{cmol}_{\mathrm{c}} \mathrm{dm}^{-3} ; \mathrm{Ca}: 2.32 \mathrm{cmol}_{\mathrm{c}} \mathrm{dm}^{-3} ; \mathrm{Mg}: 0.68 \mathrm{cmol}_{\mathrm{c}} \mathrm{dm}^{-3} ;(\mathrm{H}+\mathrm{Al})$ : $2.60 \mathrm{cmol}_{\mathrm{c}} \mathrm{dm}^{-3}$; Basal Amount: $3.14 \mathrm{cmol}_{\mathrm{c}} \mathrm{dm}^{-3}$; V: $54.7 \%$ and CTC: $5.7 \mathrm{cmol}_{\mathrm{c}} \mathrm{dm}^{-3}$.

The soil acidity correction was done 60 days before sowing the crop, applying dolomite filler limestone with $95 \%$ PRNT, to raise the soil base saturation to $60 \%$, aiming at reaching the conditions recommended for the crop . In the fertilization of sowing, $200 \mathrm{mg} \mathrm{dm}^{-3}$ of $\mathrm{P}$ and $150 \mathrm{mg} \mathrm{dm}^{-3}$ of $\mathrm{K}$ (Malavolta, 1981) were applied using simple superphosphate $\left(18 \%\right.$ of $\left.\mathrm{P}_{2} \mathrm{O}_{5}\right)$ and potassium chloride $\left(60 \%\right.$ of $\left.\mathrm{K}_{2} \mathrm{O}\right)$, respectively.

The experimental design was completely randomized in a $5 \times 2$ factorial arrangement, with four replications, totaling 40 sample units. Each unit was represented by a plastic pots with a capacity of $20 \mathrm{dm}^{3}$. The treatments were the combination of five doses of the commercial biostimulant Stimulate ${ }^{\circledR}\left(0,0.35,0.75,1.1\right.$ and $\left.1.5 \mathrm{~L} \mathrm{ha}^{-1}\right)$ by three plant hormones (kinetin, gibberellic acid and indolebutyric acid, at the concentrations of $0.009,0.005$ and $0.005 \%$ respectively), and in the presence or absence of the mixed mineral fertilizer Georaiz Leg ${ }^{\circledR}\left(150 \mathrm{~mL} \mathrm{ha}^{-1}\right.$ dose and containing $1 \%$ cobalt $5 \%$ molybdenum). Applications were applied to soybean seeds (cultivar Monsoy RR 8766), being mixed manually in plastic bags, a few minutes before sowing.

The seeds were purchased in the local commerce and verified their vigor of seeds before the use in the research. Afterwards, seed inoculation with Bradyrhizobium japonicum bacteria was carried out. The sowing was done manually, placing ten seeds per pot. Then thinning was done to keep two plants per pot. Manual irrigation was done daily to maintain the soil with $60 \%$ water retention capacity.

At 98 days after emergence, when the plants were senescence, the plants were harvested to determine the following parameters: plant height and height of insertion of the first pod (manually determined using a tape measure and results expressed in centimeters ); counting the number of pods; total number of pods, 1, 2 and 3 grain per pods, 100 seed mass and yield per plant (determined on a semi analytical scale with a precision of $0.01 \mathrm{~g}$ ).

The results were analyzed for their normality and afterwards the analysis of variance (test F) was performed and, when significant, the Tukey test was performed at 5\% probability for the presence of mixed mineral fertilizer (qualitative) and the study of regression to doses of Stimulate ${ }^{\circledR}$ (quantitative) with the aid of statistical software R (R Development Core Team, 2018).

\section{RESULTS AND DISCUSSION}

The analysis of variance through the $F$ test for the soybean cultivar Monsoy 8766 RR was significant $(p \leq 0.05)$ for the number of pods with respect to only the Stimulate ${ }^{\circledR}$ doses. However, for plant height, height of insertion of first pod, pods with 1 grain, 2 grains and 3 grains, there was no effect of the application of the doses of the biostimulant. Regarding the mineral fertilizer mixed with biostimulant, there was no difference between the levels (with and without) for the evaluated characteristics. There was also no significant interaction between biostimulant doses and mineral fertilizer use (Table 1). 
Citation: Lara Caroline Alves de Oliveira, et al., Use of biostimulants in the development and productivity of soybean. Australian Journal of Basic and Applied Sciences, 13(7): 54-59. DOI: 10.22587/ajbas.2019.13.8.8

Table 1: Minimum significant difference (DMS), coefficient of variation (CV) and mean values of plant height, insertion height of 1 st pods, numbers of pods, and with (1,2 and 3 grains), for the cultivar of Monsoy 8766 soybean as a function of the application of doses of Stimulate ${ }^{\circledR}$ with and without the application of Georaiz ${ }^{\circledR}$ Leg.

\begin{tabular}{|c|c|c|c|c|c|c|}
\hline \multirow{2}{*}{ Stimulate $^{\circledR}$} & \multirow{2}{*}{ Plant height } & \multirow{2}{*}{ Insertion $1^{\text {st }}$ pod } & \multicolumn{4}{|c|}{ Green beans } \\
\hline & & & Seedless pod & 1 grain & 2 grains & 3 grains \\
\hline$\left(\mathrm{L} \mathrm{ha} \mathbf{h}^{-1}\right)$ & \multicolumn{2}{|c|}{--------cm-------- } & \multicolumn{4}{|c|}{ 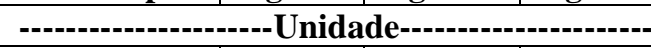 } \\
\hline 0,00 & 96,50 & 11,93 & 45,75 & 15,43 & 22,12 & 3,75 \\
\hline 0,35 & 97,06 & 13,06 & 46,68 & 15,12 & 26,93 & 5,75 \\
\hline 0,75 & 84,43 & 13,90 & 23,87 & 13,31 & 19,68 & 3,37 \\
\hline 1,10 & 91,87 & 13,84 & 13,12 & 11,25 & 22,81 & 5,25 \\
\hline 1,50 & 83,12 & 13,65 & 28,68 & 16,81 & 24,68 & 7,00 \\
\hline \multicolumn{7}{|l|}{ Georaiz $^{\circledR}$ Leg } \\
\hline With & $90,17 \mathrm{a}$ & $12,77 \mathrm{a}$ & $33,62 \mathrm{a}$ & $14,40 \mathrm{a}$ & $25,02 \mathrm{a}$ & $5,02 \mathrm{a}$ \\
\hline Without & $91,02 \mathrm{a}$ & $13,78 \mathrm{a}$ & $29,62 \mathrm{a}$ & $14,37 \mathrm{a}$ & $21,02 \mathrm{a}$ & $4,62 \mathrm{a}$ \\
\hline DMS & 10,39 & 2,364 & 15,805 & 4,224 & 4,945 & 2,050 \\
\hline Stimulate $\left.^{(}\right)(\mathrm{S})$ & $1,32 \mathrm{~ns}$ & $0,40 \mathrm{~ns}$ & $2,79 *$ & $0,86 \mathrm{~ns}$ & $1,01 \mathrm{~ns}$ & $1,68 \mathrm{~ns}$ \\
\hline Georaiz $^{\circledR}$ Leg (L) & $0,02 \mathrm{~ns}$ & $0,76 \mathrm{~ns}$ & $0,27 \mathrm{~ns}$ & $0,01 \mathrm{~ns}$ & $2,14 \mathrm{~ns}$ & $0,15 \mathrm{~ns}$ \\
\hline $\mathrm{S} \times \mathrm{L}$ & $0,35 \mathrm{~ns}$ & $0,37 \mathrm{~ns}$ & $1,04 \mathrm{~ns}$ & $0,43 \mathrm{~ns}$ & $1,32 \mathrm{~ns}$ & $1,37 \mathrm{~ns}$ \\
\hline $\mathrm{CV}(\%)$ & 17,77 & 27,57 & 77,39 & 45,47 & 32,94 & 65,80 \\
\hline
\end{tabular}

* and ns: significant $(\mathrm{P}<0.05)$, and not significant by the $\mathrm{F}$ test, respectively.

For plant height and height of first pod insertion, there was no significant effect of the biostimulant doses, obtaining plants with height between 84.43 and $83.12 \mathrm{~cm}$, respectively. In all treatments the plants remained above the ideal height (between 60 and $110 \mathrm{~cm}$ ) according to Valadão Junior et al. (2008). For the height of insertion of first pod, in the treatments where the application of the biostimulants this obtained averages near $13 \mathrm{~cm}$. But in the control treatment, the insertion height of the first pod was $11 \mathrm{~cm}$, however, these values were not statistically different. The height of insertion of the first pod is an important variable to regulate the cutting height of the harvester, aiming at obtaining maximum harvest efficiency, since it can lead to heavy losses (Albrecht et al., 2010; Cruz et al., 2016).

The use of the biostimulant for the tested cultivar favored productivity, reducing the abortion of pods at a dose of $1.10 \mathrm{~L} \mathrm{ha}^{-1}$ in $28.67 \%$, when compared to the control. Similar results were also reported by Milléo (2000), who verified that both the number of pods and the number of grains increased significantly with the use of Stimulate ${ }^{\circledR}$ biostimulants, providing a $65 \%$ increase when compared to the control treatment.

Although there was no effect of the doses of the biostimulant on the number of 1, 2 and 3 grain pods, an increase was observed in the quantity of grains as a function of the increase of the doses. Application forms are factors that can influence the number of grains produced per pod. Studies with soybean cultivation, such as Domingues et al. (2004), Klahold et al. (2008), Moterle et al., (2011) and Silveira et al. (2011), testing different doses of biostimulant in seed treatment and foliar applications, reported that soybean yield increased significantly when applied via foliar if compared to application only in seed treatment.

Regarding the application of the mixed mineral fertilizer (Georaiz ${ }^{\circledR} \mathrm{Leg}$ ), there was no significant effect for any of the evaluated variables, even though it presented in its composition the nutrients cobalt and molybdenum. Gris et al. (2005) and Silva et al. (2018), working with application of molybdenum in the soybean crop, also did not observe significant effects on their productivity. The absence of response to the addition of the composite fertilizer with the Co and Mo micronutrients may be related to the presence of adequate levels in the soil used in the study or to sufficient concentrations in the seed to meet the needs of the plants at the time of the study (Ishizuka, 1982).

Regarding the application of the biostimulant to the number of dry/empty pods, there was a linear decrease ( $\mathrm{Y}=44.927-$ 17.983x). This indicates that the number of pods decreased with increasing doses of phytohormone (Figure 1). At the dose of 1.5 $\mathrm{L} \mathrm{ha}^{-1}, 28.68$ dry pods per plant were obtained, showing a decrease of $37.31 \%$ when compared to the control. Similarly, Bertolin et al. (2010), using a dose equivalent to $0.75 \mathrm{~L} \mathrm{ha}^{-1}$, observed a $25 \%$ increase in the production of full pods in relation to the control treatment. 


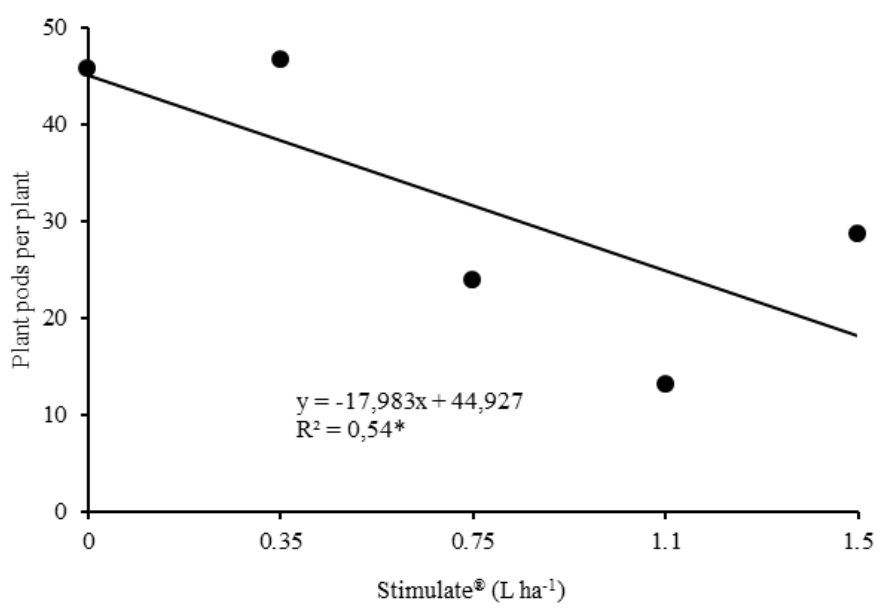

Figure 1: Dry/empty pods as a function of the use of biostimulant doses via seed treatment in Monsoy $8766 . *$ soybean cultivar significant at $5 \%$ probability.

There was also no significant effect ( $p>0.05$ ) for the application of treatments with doses of biostimulants in soybean seeds (Table 2).

For total pod production, there was an increase in this variable when $1.5 \mathrm{~L}$ ha- 1 was applied, with a mean of 47.44 pods per plant, however this increase in pod production was not significant. Carvalho et al. (2013) also report that, even though there was a difference in the production of pods per plant for the application of 0.75 and $1.0 \mathrm{~L} \mathrm{ha}^{-1}$, with 61.67 and 54.62 pods per plant respectively, this was not different statistically. Alleoni et al. (2000) and Milléo et al. (2000), studying the same biostimulant applied in foliage in bean and soybean, observed significant increases in the number of pods per plant, contrary to the results obtained in this work. In view of this, an alternative to increase the efficiency of the use of biostimulants, is to associate its application through seed treatment and foliar via in different vegetative and/or reproductive stages.

The results for mass of 100 grains corroborate with Batista Filho et al. (2013), who also report that the application of biostimulant influenced the weight of the seeds. As the doses increased, there was a reduction in the grain mass. According to Leite et al. (2009), the agronomic efficiency of bioregulators or biostimulants is significantly affected by the dosage, since excessive amounts can cause toxic effect on the plant and low utilization of plant hormones.

Table 2: Minimum significant difference (DMS - Tukey 5\%), coefficient of variation (CV) and mean values of total pod production (TPP), mass of 100 grains and production $\left(\mathrm{g}\right.$ plant $\left.^{-1}\right)$, for soybean cultivar Monsoy 8766 as a function of the application of doses of Stimulate ${ }^{\circledR}$ with and without the application of Georaiz ${ }^{\circledR}$ Leg.

\begin{tabular}{|c|c|c|c|}
\hline Stimulate $^{\circledR}$ & TPP & Mass of $\mathbf{1 0 0}$ grains & Production \\
\hline$\left(\mathbf{L ~ h a}{ }^{-1}\right)$ & ------units------ & -------g------- & -------g plant ${ }^{-1}$------- \\
\hline 0,00 & 41,12 & 14,30 & 9,99 \\
\hline 0,35 & 46,00 & 12,45 & 10,67 \\
\hline 0,75 & 36,87 & 12,93 & 8,82 \\
\hline 1,10 & 40,87 & 13,27 & 10,28 \\
\hline 1,50 & 47,43 & 12,64 & 10,58 \\
\hline \multicolumn{4}{|l|}{ Georaiz $^{\circledR}$ Leg } \\
\hline With & $44,45 \mathrm{a}$ & $13,07 \mathrm{a}$ & $10,55 \mathrm{a}$ \\
\hline Without & $40,47 \mathrm{a}$ & $13,17 \mathrm{a}$ & $9,58 \mathrm{a}$ \\
\hline DMS & 6,935 & 0,9046 & 1,587 \\
\hline Stimulate $^{\circledR}(\mathrm{S})$ & $1,262 \mathrm{~ns}$ & $2,179 \mathrm{~ns}$ & $0,744 \mathrm{~ns}$ \\
\hline Georaiz $^{\circledR}$ Leg (L) & $1,370 \mathrm{~ns}$ & $0,062 \mathrm{~ns}$ & $1,556 \mathrm{~ns}$ \\
\hline $\mathrm{S} \times \mathrm{L}$ & $1,997 \mathrm{~ns}$ & $0,270 \mathrm{~ns}$ & $1,506 \mathrm{~ns}$ \\
\hline $\mathrm{CV}(\%)$ & 25,29 & 10,67 & 24,41 \\
\hline
\end{tabular}

* and ns: significant $(\mathrm{P}<0.05)$, and not significant by the $\mathrm{F}$ test, respectively.

By observing the productivity results per plant (Table 2), it was verified that even though not statistically different, the dose of $0.35 \mathrm{~L} \mathrm{ha}^{-1}$ provided a $6.37 \%$ increase in grain yield in relation to the control treatment. More expressive results observed in the present study were described by Batista Filho et al. (2013) tested the same biostimulant found a $39 \%$ increase in productivity in relation to the control treatment for the soybean crop.

Some studies have shown that soybean plants generated from seeds treated with biostimulants produce seeds with higher oil and protein content (Ávila et al., 2008). The use of biostimulants in the treatment of seeds results in plants with greater capacity to produce seeds with high germinative power. In addition, these may present higher amounts of normal and high-vigor seedlings (Melo et al., 2015). 
Despite the advantages of using biostimulants, some factors may influence the efficiency of such products. This can occur due to a great variability in the results obtained depending on the crop, the environment and the agricultural practices employed. In addition, it is known that hormones rarely act alone, even when a response in the plant is attributed to the application of a single plant regulator, the tissue that received the application contains endogenous hormones that contribute to the responses obtained (Cobucci et al. 2008).

Dourado Neto et al. (2014), in studies with biostimulants, stress that their effects may be more prominent under stress conditions, since these products are composed of hormones that can aid the defense mechanisms of plants and promote their growth and development. Therefore, research with biostimulants should consider conditions of stress and normal conditions, to verify in which condition the best response occurs. Few studies have demonstrated the action of biostimulants and the possible interaction with other factors, interfering in the quality of the seeds; but there are reports on the isolated effect of the biostimulant such as Ávila et al. (2008) with soybean and Santos Neta et al. (2016). These studies report quality seeds after treatment with biostimulants.

\section{CONCLUSION}

The use of biostimulants promotes a reduction of $37.31 \%$ in the number of dry pods and has no influence on the height of plants, height of insertion of 1 st pods, and number of pods with 1, 2 or 3 grains.

The application of mineral fertilizer composed of cobalt and molybdenum does not influence the characteristics evaluated.

\section{ACKNOWLEDGEMENT}

The authors acknowledge the financial support from CAPES / Brazil.

\section{FUNDING INFORMATION}

'Not applicable' for that section.

\section{CONFLICT OF INTEREST}

Authors declare no conflict of interest.

\section{REFERENCES}

Albrecht, L.P., A.L. Braccini, and C.A. Scapim. (2010). Quality of soybean seeds produced under management with bioregulator. Journal of Seed Science, 32 (4):39-48.

Almeida, G., and J. Rodrigues, J. 2016. Development of plants through the interference of auxins, cytokinins, ethylene and gibberellins. Brazilian Journal of Applied Technology for Agricultural Science, 9(3): 111-117.

Almeida, A.S., M.Â.A. Tillmann, F.A. Villela, and M.S. Pinho. 2009. Bioactivator in the physiological performance of carrot seeds. Revista Brasileira de Sementes, 31(3): 087- 095.

Ávila, M.R., A.L. Braccini, C.A. Scapim, L.A. Albrecht, T.A. Tonin, and M. Stülp. (2008). Bioregulator application, agronomic efficiency, and quality of soybean seeds. Scientia Agricola, 65(6):604-612. http://dx.doi.org/10.1590/S010390162008000600006

Batista Filho, C.G., K. Marco, R. Dallacort, A. Santi, M.H. Inoue, and E.S. Silva. 2013. Effect of Stimulate ${ }^{\circledR}$ on the agronomic characteristics of soybean. Acta Iguazu, 2(4): 76-86.

Bertolin, D.C., M.E. Sá, O. Arf, E. Furlani Junior, A.D.S. Colombo, and F.L.B.M. Carvalho. 2010. Increase in soybean yield with the application of biostimulants. Bragantina, 69(2): 339-347. http://dx.doi.org/10.1590/S0006-87052010000200011

Carvalho, J.C., C.A. Viecelli, and D.K. Almeida. 2013. Productivity and development of soybean crop by use of plant regulator. Acta Iguazu, 2(1): 50-60.

Calvo P., L. Nelson, and J.W. Kloepper. 2014. Agricultural uses of plant biostimulants. Plant Soil 383(1):3-41.

Castro, P.R., C.E. De and E.L. Vieira. 2003. Biorreguladores e bioestimulantes na cultura do milho. In: Fancelli, A.L., Dourado Neto, D. (Ed.) Milho: estratégias para alta produtividade. Piracicaba, p. 99-115.

Cobucci, T., A. Nascente, C.R. Pereira Filho, A. Machado, K. Oliveira, and A. Carvalho. 2008. Efeitos de reguladores vegetais aplicados em diferentes estágios de desenvolvimento do feijoeiro comum. In Embrapa Arroz e Feijão-Artigo em anais de congresso. In: Congresso Nacional de Pesquisa De Feijão, 9., 2008, Campinas. Ciência e tecnologia na cadeia produtiva do feijão. Campinas: Instituto Agronômico, 2008. https://www.alice.cnptia.embrapa.br/alice/bitstream/doc/216175/1/243.pdf

Cruz, S.C.S., D.G.S. Junior, D.M.A. Dos Santos, , L.O. Lunezzo, and C.G. Machado. 2016. Soybean cultivation under different sowing densities and spatial arrangements. Revista de Agricultura Neotropical, 3(1): 1-6. https://doi.org/10.32404/rean.v3i1.431

Domingues, M.C.S., J.D. Rodrigues, and R.C. Moreira. 2004. Efeito de reguladores vegetais (auxina, giberelina e citocinina) na produtividade da cultura da soja (Glycine $\max$ (L.) Merrill cv. IAC-48). In: Congresso Brasileiro de Soja, 3., Foz do Iguaçu. Anais... Foz do Iguaçu. Embrapa Soja. 228: 336-336. 
Citation: Lara Caroline Alves de Oliveira, et al., Use of biostimulants in the development and productivity of soybean. Australian Journal of Basic and Applied Sciences, 13(7): 54-59. DOI: 10.22587/ajbas.2019.13.8.8

Dourado Neto, D., G.J.A. Dario, A.P.P. Barbieri, and T.N. Martin. 2014. Biostimulant action on the agronomic performance of corn and beans. Bioscience Journal, 30(3): 371-379.

Empresa Brasileira de Pesquisa Agropecuária. 2009. Manual de análises químicas de solos, plantas e fertilizantes. Brasília-DF: Embrapa Informação Tecnológica; Brasília, DF: Embrapa Solos, 627p.

Hirakuri, M.H., and J.J. Lazzarotto. 2014. O agronegócio da soja nos contextos mundial e brasileiro. Londrina: Embrapa Soja, 915. https://www.infoteca.cnptia.embrapa.br/bitstream/doc/990000/1/Oagronegociodasojanoscontextosmundialebrasileiro.pdf

Instituto Brasileiro de Geografia e Estatística. Produção Agropecuária Estadual - Brasil: Setembro de 2019. Disponível em: <http://www.ibge.gov.br/cidadesat/topwindow.htm?1> Acesso em: 06 mai. 2019.

Ishizuka, J. 1982. Characterization of molybdenum absorption and translocation in soybean plants. Soil Science Plant Nutrition, 28(1): 63-77.

Klahold, C.A., V.F. Guimarães, M.M. Echer, A. Klahold, R.L. Contiero, and A. Becker. 2006. Response of soybean (Glycine max L. Merrill) to the action of biostimulant. Acta Scientiarum. Agronomy, 28(2): 179-185. http://dx.doi.org/10.4025/actasciagron.v28i2.1032

Leite, P.G.H., C.A.C. Crusciol, G.P.P. Lima, and M.A. Silva. 2009. Plant regulators and invertases activity in sugarcane in the middle of the harvest. Ciência Rural, 39(3): 718- 725.

Lopes, J.F., F.C. Coelho, O.J.P. Rangel, W.S. Rabello, A. Gravina, and H.D. Vieira. 2015. Foliar fertilization with nickel and molybdenum in common bean cv. Ouro Vermelho. Ceres, 61(2): 234-240.

Malavolta, E. 1981. Manual de Química Agrícola: Adubos e Adubação. Editora Agronômica Ceres. São Paulo, Brasil. 594p.

Melo, L.D.F.A., E.P. Gonçalves, L.N. Ralph, J.S. Viana, and S.C.A. Silva. (2015). Physiological and physical quality of seeds from peanut seeds and plants under the influence of fertilizer and biostimulant. American Journal of Plant Sciences, v.6, p.1594-1606. http://dx.doi.org/10.4236/ajps.2015.69160

Milléo, M.V.R., and M.A. Monferdini. 2000. Avaliação da eficiência agronômica de diferentes dosagens e métodos de aplicação de Stimulate ${ }^{\circledR}$ em soja. In: Congresso Brasileiro de Soja, 3., Foz do Iguaçu. Anais... Foz do Iguaçu. 2000. 18p.

Moterle, L.M., R.F. Santos, C.A. Scapim, A.L. Braccini, C.M. Bonato, and T. Conrado. (2011). Effect of bioregulator on germination and vigor of soybean seeds. Ceres, 58(5): 651-660. http://dx.doi.org/10.1590/S0034-737X2011000500017

Nardi S., D. Pizzeghello, M. Schiavon, and A. Ertani. 2016. Plant biostimulants: physiological responses induced by protein hydrolyzed-based products and humic substances in plant metabolism. Sci. Agricola 73(1):18-23.

Prado, R.M., W. Natale, and M.C. Mouro. 2007. Zinc sources applied via seed in the nutrition and initial growth of corn cv. Fort. Bioscience Journal, 23(.2): 16-24.

R Development Core Team. R: A language and environment for statistical computing. Viena: R Foundation for Statistical Computing; 2018. Disponível em: https://www.R-project.org/>. Acesso em: 02/01/2018.

Santos, C.M.G., and E.L.Vieira. 2005. Effect of biostimulant on seed germination, seedling vigor and initial cotton growth. Magistra, 17(3): 124-130.

Santos, H.G., P.K.T. Jacomine, L.H.C. Anjos, V.A. Oliveira, J.F. Lumbreras, M.R. Coelho, J.A. Almeida, T.J.F. Cunha, and J.B. Oliveira. 2013. Sistema Brasileiro de Classificação de Solos. $3^{\mathrm{a}}$ ed. Brasília: Embrapa Solos, 353 p. http://www.infoteca.cnptia.embrapa.br/infoteca/handle/doc/1094003

Sfredo, G.J., and M.C.N. Oliveira. 2010. Soja: molibdênio e cobalto. Londrina: Embrapa Soja, 2010. (Documentos / Embrapa Soja, 322). 322p. http://ainfo.cnptia.embrapa.br/digital/bitstream/item/18872/1/Doc_322_online1.pdf

Silva, A.F., E.L. Schoninger, S. Monteiro, G. Caione, M.A.C. Carvalho, F.C. Dalchiavon, and R. Noetzold. 2011. Inoculation with Bradyrhizobium and forms of application of cobalt and molybdenum in the soybean crop. Agrarian, 4(12), 98-104.

Silveira, O.S., E.L. Vieira, C.G. Santos, and C.A. Gonçalves. 2011. Stimulate $®$ in seed germination, seedling vigor, initial growth and soybean yield. Magistra, 23(1): 67-74.

Souza Neta, M.L., F.A. Oliveira, S.B. Torres, A.A.T. Souza, S.M.C. Carvalho, and C.P. Benedito. (2016). Residual effect of bur gherkin seed treatment with biostimulant under salt stress. Journal of Seed Science, 38(3), 219226. https://dx.doi.org/10.1590/2317-1545v38n3163796

Stoller do Brasil. 1998. Stimulate Mo em hortaliças. Cosmópolis: Stoller do Brasil. Divisão Arbore, 1:1.

Taiz, L., and E. Zeiger. 2004. Plant Physiology. 3.ed. Porto Alegre: Artmed, 719p. http://www.revistaea.org/pf.php?idartigo=2354

Valadão Júnior, D., A.C. Bergamin, L.R. Venturoso, J.A. Schlindwein, B.O. Caron, ando D. Schmidt. 2008. Phosphate fertilization in soybean crop in Rondônia. Scientia Agraria, 9(3): 369-375.

Vasconcelos, A.C.F., X. Zhang, E.H. Ervin, and J.C. Kiehl. 2009. Responses of antioxidant enzymes to biostimulants in maize and soybean plants under water stress. Scientia Agricola, 66(3): 395-402. https://doi.org/10.1590/S0103-90162009000300015

Weber, F. 2011. Uso de bioestimulantes no tratamento de sementes de soja. (Pelotas), 2011. 28 f. Dissertation (Master of Science). Faculty of Agronomy Eliseu Maciel, Federal University of Pelotas, 28p. http://guaiaca.ufpel.edu.br:8080/handle/123456789/1528 